\title{
Immunoglobulin gene rearrangement and antigenic profile confirm B cell origin of primary cerebral lymphoma and indicate a mature phenotype
}

\author{
W J SMITH, * J A GARSON, $\dagger$ S P BOURNE, $\ddagger$ J T KEMSHEAD $\dagger$ H B COAKHAM $\ddagger$ \\ From the *Department of Histopathology, University College Medical School, $\uparrow$ ICRF Oncology Laboratory, \\ Institute of Child Health, London, and the $\ddagger$ Department of Neurosurgery, Frenchay Hospital, Bristol
}

SUMMARY Six cases of primary cerebral lymphoma were immunophenotyped and analysed by Southern blotting to determine the clonality and lineage of these neoplasms. Molecular analysis showed that they were of B cell origin, and the rearrangement of both heavy and light chain immunoglobulins in malignant cells showed that they were monoclonal populations of mature B cells.

The characterisation of the genetic configuration of the immunoglobulin genes in these lymphomas is important because the ability to distinguish between primary lymphoma of the central nervous system and other malignant cerebral tumours has important implications for treatment and survival.

Primary cerebral lymphoma is relatively rare, comprising between 0.3 and $1.5 \%$ of all intracranial tumours.' Until recently, several diagnostic labels were applied to this tumour, including reticulum cell sarcoma and microglioma. The precise cell of origin of primary cerebral lymphoma is a subject of controversy, although an association between these neoplasms and non-Hodgkin's lymphoma has been acknowledged. ${ }^{2}$ The ability to distinguish between primary lymphoma of the central nervous system (CNS) and other malignant cerebral tumours has clinical consequences, as many cerebral lymphomas are radiosensitive. ${ }^{3}$ The use of monoclonal antibodies has facilitated such differential diagnosis in certain cases. ${ }^{4}$ An immunohistochemical study of 20 cerebral lymphomas showed binding by the monoclonal antibody $\mathrm{B} 1$, which recognises the antigen CD20, indicating that they were $B$ cell malignancies. ${ }^{4}$ The presence of reactive $\mathrm{T}$ cells in cerebral lymphomas, however, may lead to difficulty in diagnosis if the immunohistochemical data are not clear.

The use of molecular techniques to determine the lineage and clonality of lymphoproliferative conditions has become more widespread in the past few years due to the availability of recombinant DNA probes encoding the immunoglobulin and $T$ cell receptor genes. ${ }^{5}$ These genes are organised in the genome in a segmental fashion and undergo somatic rearrangement during commitment to the $B$ or $T$ cell

Accepted for publication 14 September 1987 lineage. ${ }^{6}$ Each lymphocyte undergoes a specific rearrangement of its immunoglobulin or $T$ cell receptor genes, which is unique to the cell. Consequently, if a particular cell undergoes a clonal expansion, the whole clone can be identified by its genetic configuration using the Southern blot technique. The ability to distinguish between monoclonal and reactive proliferations of lymphocytes is of considerable benefit in the diagnosis of lymphoma.

We analysed six cases of primary cerebral lymphomas by immunophenotyping and by Southern blot analysis to determine the clonality and lineage of these neoplasms.

\section{Material and methods}

Cases were diagnosed as primary cerebral lymphoma on the basis of histological and immunohistochemical studies. DNA was extracted from snap frozen biopsy specimens, in which the presence of lymphoma had $N$ been confirmed by standard methods. ${ }^{7}$ After incubation with a restriction enzyme (EcoR1, HindIII, or BgIII), the restriction fragments were separated according to size by gel electrophoresis and transferred to a nylon membrane (Gene-Screen Plus, DuPont) by Southern blotting. ${ }^{8}$ Recombinant DNA probes (table 1) ${ }^{79-11}$ were radiolabelled with ${ }^{32} \mathrm{P}$-dCTP by oligo labelling ${ }^{12}$ and hybridised to the filter. After stringent washing the filter was exposed to pre-fogged $x$-ray film at $-70^{\circ} \mathrm{C}$ for between two and four days.

The immunohistochemical studies were carried out 
Table 1 Recombinant DNA probes

\begin{tabular}{|c|c|c|}
\hline Probe & Code name & Reference \\
\hline $\begin{array}{l}\text { Heavy chain, } \\
\text { joining region }(\mathrm{Jh})\end{array}$ & C76R51A & 7 \\
\hline 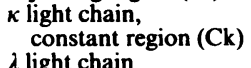 & pUCR 17 & 9 \\
\hline $\begin{array}{l}\lambda \text { light chain } \\
\text { constant region }(C \lambda)\end{array}$ & pUCA5 & 10 \\
\hline $\begin{array}{l}T \text { cell receptor } \\
\beta \text { chain }(\mathbf{C} \boldsymbol{\beta})\end{array}$ & $\mathrm{C} \beta 2$ & 11 \\
\hline
\end{tabular}

Table 2 Monoclonal antibodies

\begin{tabular}{|c|c|c|}
\hline $\begin{array}{l}\text { Monoclonal } \\
\text { antibody }\end{array}$ & Tissue specificity & Source/Reference \\
\hline $\begin{array}{l}\text { 2D1 } \\
\text { LC (PD7/26 }\end{array}$ & Pan-leukocyte and lymphoma & Dr P Beverley ${ }^{13}$ \\
\hline $\begin{array}{l}\text { \& } 2 \mathrm{~B} 11) \\
\text { B1 } \\
\text { FMC7 } \\
\text { UCHT1 } \\
\text { Leu 2a }\end{array}$ & $\begin{array}{l}\text { Pan-leukocyte and lymphoma } \\
\text { Pan-B cell (CD20) } \\
\text { Mature B cell } \\
\text { Pan-T cell (CD3) } \\
\text { Suppressor/cytotoxic } \\
\text { T cells (CD8) }\end{array}$ & $\begin{array}{l}\text { Dakopatts } \\
\text { Coulter Clone }^{15} \\
\text { Sera Lab }{ }^{16} \\
\text { Dr P Beverley }{ }^{17} \\
\text { Becton Dickinson }{ }^{18}\end{array}$ \\
\hline Leu 3a & $\begin{array}{l}\text { Helper/inducer T } \\
\text { cells (CD4) }\end{array}$ & Becton Dickinson ${ }^{18}$ \\
\hline Leu 7 & $\begin{array}{l}\text { Natural killer cells } \\
\text { and large granular } \\
\text { lymphocytes }\end{array}$ & Becton Dickinson ${ }^{19}$ \\
\hline UJ13A & Pan-neuroectodermal & Dr JT Kemshead ${ }^{20}$ \\
\hline
\end{tabular}

on frozen and fixed tissues using the antibodies detailed in table $2 .{ }^{13-20}$ Frozen sections $(6 \mu \mathrm{m})$ were hydrated for five minutes in phosphate buffered saline (PBS) on gelatine coated slides. After removing excess PBS $100 \mu \mathrm{l}$ of diluted monoclonal antibody was applied and incubated for 30 minutes at room temperature. Non-immune ascitic fluid was used as a negative control. Two washes in PBS were followed by a 30 minute incubation with $100 \mu$ l of fluorescein conjugated, affinity purified, goat anti-mouse immunoglobulin. Unbound conjugate was removed by two washes in PBS and the sections were mounted in $90 \%$ glycerol $/ 10 \%$ PBS for examination by epifluorescence microscopy. Haematoxylin and eosin staining was performed on subsequent sections to facilitate the orientation and interpretation of the fluorescence results.

Formalin fixed paraffin embedded tissue sections were dewaxed and endogenous peroxidase activity inhibited by immersion in $\mathbf{0 . 5 \%}$ hydrogen peroxidase in methanol for 30 minutes. The protocol outlined for frozen sections was followed, except that the fluorescein conjugate was replaced by peroxidase conjugated goat antimouse immunoglobulin. The bound antibody was visualised by incubation with diaminobenzidine. Sections were counterstained with Harris's haematoxylin, dehydrated through an alcohol series, and mounted.

\section{Results}

Immunostaining of all the biopsy sections from this series of cerebral malignancies with the pan-leucocyte antibody $2 \mathrm{D} 1$ and the pan-B cell reagent $\mathrm{B} 1$ confirmed that they were B cell populations (table 3). Membrane rather than cytoplasmic binding was observed. In all the samples tested with FMC7 $20-70 \%$ of the cells expressed the antigen recognised by this antibody. A sparse population of cells $(5 \%)$ bound the anti-T cell antibodies. None of the cells was immunoreactive with the monoclonal antibodies that recognise antigens expressed by natural killer cells (Leu7) or neuroectodermal tissue (UJ13A).

The molecular analysis of the six primary cerebral lyphomas (table 4) confirmed the immunohistochemical data which showed that they were B cell populations (table 4). The demonstration of a population of cells all possessing the same rearrangement of the Jh locus indicates the presence of a monoclonal B cell population. The novel restriction fragments were not generated by DNA polymorphisms as they were detected in all three restriction digests analysed for each case. The germline fragments which hybridised to the $\mathrm{Jh}$ probe originated from the normal cells in the biopsy specimen or, in case B7, the non-rearranged Jh allele in the neoplastic clone. In all cases, with the exception of B7, both alleles of the immunoglobulin heavy chain gene had undergone somatic recombination. The intensities of the non-germline bands on the autoradiographs indicated that the neoplastic clones comprised a high proportion of the cell populations examined.

Immunohistochemical study of these cases did not include an analysis of the immunoglobulin light chains

Table 3 Immunophenotype of cases

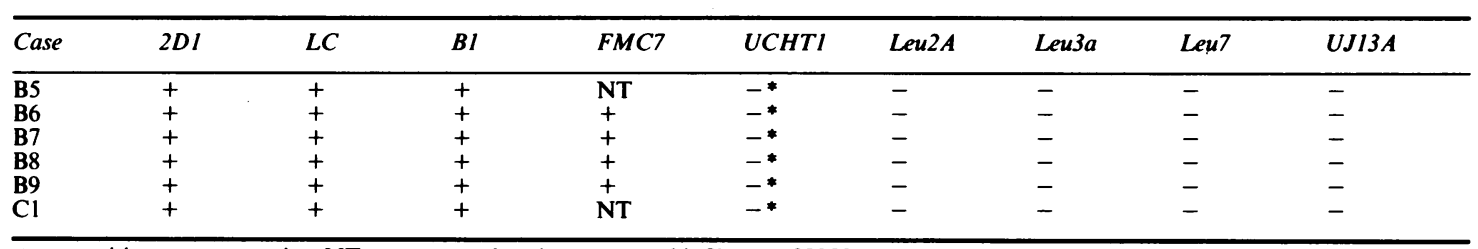

$+=$ positive; $-=$ negative; NT $=$ not tested; $-^{*}=$ scattered infiltrate of UCHT1 positive cells $(<5 \%)$ present. 


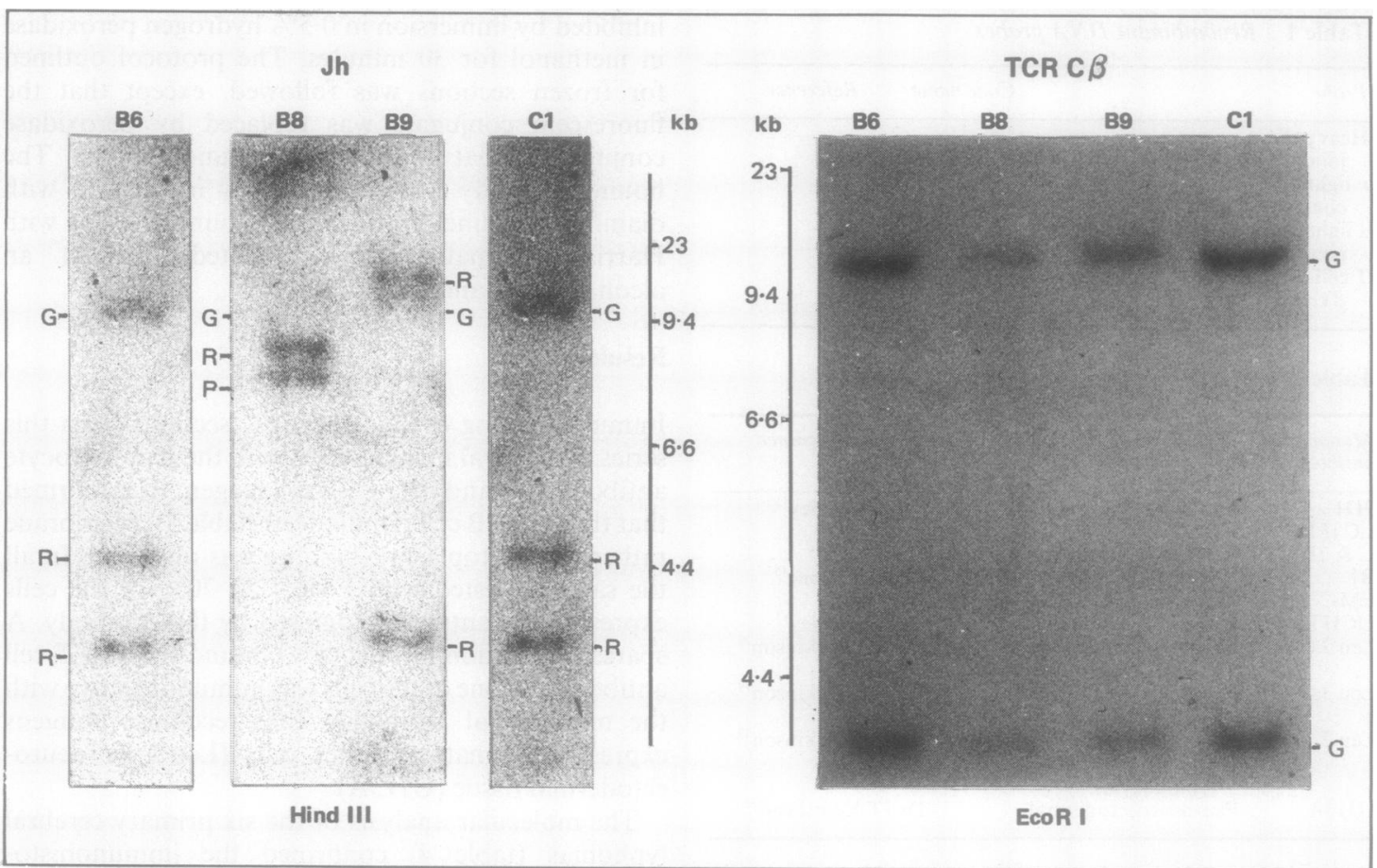

Figure Illustration of immunoglobulin heavy chain joining region (Jh) gene rearrangement and germline configuration of genes encoding $T$ cell receptor $\beta$ chain constant region $(C \beta)$ in cases $B 6, B 8, B 9$ and $C 1$ of primary cerebral lymphoma. $G=$ germline; $R=$ rearranged; $K b=$ sizes of molecular weight markers in kilobases.

present on the cell surface. Rearrangement of the Ck genes was detected in four of the five cases in which it was possible to examine the configuration of the light chain genes (table 4). Clonal deletion of the $\mathrm{Ck}$ genes had probably occurred in case B8. The patterns of hybridisation to the $\mathrm{Jh}$ probe in this case indicated that about $80 \%$ of the cell population was monoclonal while the remaining $20 \%$ possessed germline immunoglobulin heavy chain genes. On probing with the $\mathbf{C k}$ probe, the band representing the germline fragment was about $20 \%$ of the intensity which would have been observed if all the cells had possessed non-rearranged $\mathrm{Ck}$ genes. No other restriction fragments complemen- tary to the $\mathrm{Ck}$ probe were observed. These data suggest that the malignant cells $(80 \%)$ had undergone a clonal deletion of their $\mathrm{Ck}$ genes.

The $C \lambda$ locus is highly polymorphic, and comparing its configuration in normal and putative lymphoma samples from the same patient facilitates the identification of a rearrangement at this locus. ${ }^{10}$ Configurations of the $\mathrm{C} \lambda$ loci similar to those of published germline patterns ${ }^{10}$ were detected in four of five samples (table 4). In case B8 a restriction fragment which hybridised to the $C \lambda$ probe was observed in addition to the germline fragments. Although no control tissue from this patient was available, the

Table 4 Genotypic results

\begin{tabular}{|c|c|c|c|c|c|c|c|}
\hline \multirow[b]{2}{*}{ Case No } & \multicolumn{3}{|l|}{$\boldsymbol{J h}$} & \multirow{2}{*}{$\begin{array}{l}C k \\
B g I I I\end{array}$} & \multirow{2}{*}{$\begin{array}{l}C \lambda \\
\text { HindIII }\end{array}$} & \multicolumn{2}{|l|}{$C \boldsymbol{B}$} \\
\hline & EcoRI & HindIII & $B g I I I$ & & & HindIII & EcoRI \\
\hline $\begin{array}{l}\text { B5 } \\
\text { B6 } \\
\text { B7 } \\
\text { B8 } \\
\text { B9 } \\
\text { C1 }\end{array}$ & $\begin{array}{l}\mathbf{G}+\mathbf{R} / \mathbf{R} \\
\mathbf{G}+\mathbf{R} / \mathbf{R} \\
\mathbf{N D} \\
\mathbf{G}+\mathbf{R} / \mathbf{R} \\
\mathbf{G}+\mathbf{R} / \mathbf{R} \\
\mathbf{G}+\mathbf{R} / \mathbf{R}\end{array}$ & $\begin{array}{l}\mathbf{G}+\mathbf{R} / \mathbf{R} \\
\mathbf{G}+\mathbf{R} / \mathbf{R} \\
\mathbf{G}+\mathbf{R} \\
\mathbf{G}+\mathbf{R} / \mathbf{R} \\
\mathbf{G}+\mathbf{R} / \mathbf{R} \\
\mathbf{G}+\mathbf{R} / \mathbf{R}\end{array}$ & $\begin{array}{l}\mathbf{N D} \\
\mathbf{G}+\mathbf{R} / \mathbf{R} \\
\mathbf{G}+\mathbf{R} \\
\mathbf{G}+\mathbf{R} / \mathbf{R} \\
\mathbf{G}+\mathbf{R} / \mathbf{R} \\
\mathbf{G}+\mathbf{R} / \mathbf{R}\end{array}$ & $\begin{array}{l}\text { Insufficient DNA } \\
\mathbf{G}+\mathbf{R} / \mathbf{R} \\
\mathbf{G}+\mathbf{R} / \mathbf{R} \\
\mathbf{G}+\mathbf{D} \\
\mathbf{G}+\mathbf{R} \\
\mathbf{R} / \mathbf{R}\end{array}$ & $\begin{array}{l}\mathbf{G} \\
\mathbf{G} \\
\mathbf{G} \\
\mathbf{G}\end{array}+\mathbf{R}$ & $\begin{array}{l}\mathbf{G} \\
\mathbf{G} \\
\mathbf{G} \\
\mathbf{G} \\
\mathbf{G}\end{array}$ & $\begin{array}{l}\mathbf{G} \\
\mathbf{G} \\
\mathbf{G} \\
\mathbf{G} \\
\mathbf{G}\end{array}$ \\
\hline
\end{tabular}

$\mathbf{G}=$ germline genetic configuration; $\mathbf{R}=$ rearranged genetic configuration; $\mathrm{D}=$ deleted; $\mathrm{ND}=$ not done. 
Table 5 Clinical details

\begin{tabular}{|c|c|c|c|c|c|c|c|}
\hline Case & Age/sex & Site & $\begin{array}{l}\text { Original } \\
\text { histological } \\
\text { diagnosis }\end{array}$ & $\begin{array}{l}\text { Immunological } \\
\text { diagnosis }\end{array}$ & $\begin{array}{l}\text { Genetic } \\
\text { diagnosis }\end{array}$ & Radiation & Survival \\
\hline$\overline{\mathrm{B} 5}$ & $77 / \mathrm{F}$ & $\begin{array}{c}\text { Corpus } \\
\text { callosum }\end{array}$ & Lymphoma & $\begin{array}{l}\text { B cell } \\
\text { lymphoma }\end{array}$ & $\begin{array}{l}\text { B cell } \\
\text { lymphoma }\end{array}$ & No & 1 month \\
\hline B6 & $69 / M$ & Temporal & $\begin{array}{c}\text { ?Lymphoma } \\
\text { ?secondary } \\
\text { carcinoma }\end{array}$ & $\begin{array}{l}\text { B cell } \\
\text { lymphoma }\end{array}$ & $\begin{array}{l}\text { B cell } \\
\text { lymphoma }\end{array}$ & Yes & 2 years \\
\hline B7 & $58 / \mathrm{F}$ & Temporal & $\begin{array}{l}\text { Undifferentiated } \\
\text { metastasis }\end{array}$ & $\begin{array}{l}\text { B cell } \\
\text { lymphoma }\end{array}$ & $\begin{array}{l}\text { B cell } \\
\text { lymphoma }\end{array}$ & No & 2 months \\
\hline B8 & $65 / F$ & Fronto-temporal & Lymphoma & $\begin{array}{l}\text { B cell } \\
\text { lymphoma }\end{array}$ & $\begin{array}{l}\text { B cell } \\
\text { lymphoma }\end{array}$ & $\begin{array}{l}\text { No } \\
\text { No }\end{array}$ & $\begin{array}{l}3 \text { weeks } \\
3 \text { weeks }\end{array}$ \\
\hline B9 & $68 / F$ & Frontal & $\begin{array}{l}\text { ?Lymphoma } \\
\text { secondary } \\
\text { carcinoma }\end{array}$ & $\begin{array}{l}\text { B cell } \\
\text { lymphoma }\end{array}$ & $\begin{array}{l}\text { B cell } \\
\text { lymphoma }\end{array}$ & Yes & 4 years \\
\hline $\mathrm{Cl}$ & $46 / F$ & Occipito-parietal & Lymphoma & $\begin{array}{l}\text { B cell } \\
\text { lymphoma }\end{array}$ & $\begin{array}{l}\text { B cell } \\
\text { lymphoma }\end{array}$ & Yes & 2 years, alive \\
\hline
\end{tabular}

presence of this fragment in combination with the apparent clonal deletion of the $\mathrm{Ck}$ locus indicates a rearrangement at the $C \lambda$ locus.

The state of the genes encoding the constant region of the $\beta$ chain of the $T$ cell receptor was examined in each case with two restriction enzymes EcoR1 and HindIII. There was no evidence of genetic rearrangement at this locus in any sample (table 4).

\section{Discussion}

The combination of immunohistochemical and genetic studies on this series of primary cerebral lymphomas confirmed that they were B cell malignancies. The rearrangement of both the heavy and light chain immunoglobulin genes in these cells showed that they were monoclonal populations of mature B cells. Despite the presence of reactive $T$ cells, recognised by anti- $T$ cell antibodies, no evidence of a monoclonal $T$ cell population was identified by molecular techniques. Although the Southern blotting technique is relatively time consuming, it is useful in cases in which the clonality or lineage of a lympho-proliferative population is not clarified by immunohistochemical techniques.

In our experience the immunohistochemical demonstration of surface immunoglobulin light chains in cerebral tissue is unsatisfactory. The presence of immunoglobulin released by necrotic tissue leads to non-specific reactivity of the anti-light chain antibodies. "Freeze and thaw" and "crush" artefacts adversely affect the interpretation of these immunohistochemical data. Immunoglobulin gene rearrangement occurs during development in a hierarchical manner: immunoglobulin heavy chain genes are rearranged before light chain genes. ${ }^{21}$ The hierarchy extends to light chain genes: $\kappa$ chain gene rearrangement precedes that of $\lambda$. The demonstration of light chain gene rearrangement in the primary cerebral lymphomas indicates that they possess a relatively mature genotype. This agrees with the immunophenotypic data as the monoclonal antibody FMC7 recognises an antigen expressed by mature B cells. ${ }^{16}$

Studies on non-Hodgkin's lymphoma biopsy specimens from various sites have shown that most lymphomas that were immunoreactive with the monoclonal antibody B1 possessed rearranged immunoglobulin genes. ${ }^{22}{ }^{23}$ This was true even if the percentage of cells expressing the antigen was low. Molecular analysis has proved to be of particular value in the characterisation of "null" non-Hodgkins lymphomas, most of which possess rearranged immunoglobulin genes. ${ }^{24} 25$ The data presented in this paper on primary cerebral lymphomas correlate with those already published on non-Hodgkins lymphomas.

The clinical consequences of identifying cerebral lymphoma are illustrated by cases B6 and B9 (table 5). The original histological diagnoses could not differentiate between lymphoma and secondary carcinoma. Immunophenotyping and genetic analysis confirmed that lymphoma was present which proved to be radiosensitive in these cases. Similarly, genetic and immunological analysis of case B7 showed the presence of $B$ cell lymphoma rather than an undifferentiated metastasis. The correct diagnosis of this case was made retrospectively (on frozen tissue) as part of an immunohistological review of undifferentiated tumours. The patient had not received radiotherapy and died two months after biopsy. This contrasts with the relatively longer survivals of those patients who had received radiotherapy (table 5).

The characterisation of the genetic configuration of the immunoglobulin genes in these lymphomas would be of benefit in the event of a patient developing a further tumour. If the new neoplasm possessed a genetic configuration identical with that of the original lymphoma, it would indicate the re-emergence of the original B cell clone.

In conclusion, we have shown that the primary cerebral tumours studied in this series by immun- 
ological and genetic analysis were B cell malignancies, arrested at the mature end of the B cell differentiation pathway. These methods provide the neuropathologist with information which may have important clinical implications.

We thank Professor P G Isaacson, in whose department part of this study was undertaken, and Dr D B Brownwell for her diagnostic skills. WJS is supported by the Cancer Research Campaign, JAG and JTK by the Imperial Cancer Research Fund, and SPB by the Bristol Brain Research Foundation.

\section{References}

1 Spillane JA, Kendall BE. Cerebral lymphoma: clinical radiological correlation. J Neurol Neurosurg Psychiatry 1982;45:199-208.

2 Henry JM, Heffner RR, Dillard SH, Earle K, Davis RL. Primary malignant lymphomas of the central nervous system. Cancer 1974;34:1293-302.

3 Letendre L, Banks PM, Reese DF, Miller RH, Scanlon PW, Kiely JM. Primary lymphoma of the central nervous system. Cancer 1982;49:939-43.

4 Garson J, Bourne S, Allan P, Brownell DB, Coakham HB. Antigenic analysis of primary brain lymphomas using a monoclonal antibody panel. J Neuropathol Exp Neurobiol (in press).

5 Smith WJ. Gene rearrangement in leukaemias and lymphomas. In: Kernshead JT, ed. Monoclonal antibodies and molecular probes in paediatric solid tumours. Florida: CRC Press, 1987.

6 Hood L, Kronenberg M, Hunkapiller T. T cell antigen receptors and the immunoglobulin supergene family. Cell 1985;40:225-9.

7 Flanagan JD, Rabbitts TH. The sequence of an immunoglobulin epsilon heavy chain constant region gene and evidence for three non-allelic genes. EMBO J 1982;1:655-60.

8 Southern EM. Detection of specific sequences among DNA fragments separated by gel electrophoresis. J Mol Biol 1975;98:503-17.

9 Bentley DL, Rabbitts TH. Evolution of immunoglobulin V genes: evidence that recently duplicated human $\mathrm{Vk}$ sequences have diverged by gene conversion. Cell 1983;3:181-9.

10 Rabbitts TH, Forster A, Matthews JG. The break-point of the Philadelphia chromosome 22 in chronic myeloid leukaemia is distal to the immunoglobulin $\lambda$ light chain constant region genes. Mol Biol Med 1983;1:11-19.

11 Sims JE, Tunnacliffe A, Smith WJ, Rabbitts TH. Complexity of human $\mathrm{T}$ cell receptor $\beta$ chain constant and variable region genes. Nature 1984;312:541-5.
12 Feinberg AP, Vogelstein B. A technique for radio-labelling DNA restriction fragments to high specific activity. Anal Biochem 1983;132:6-13.

13 Pizzolo G, Sloane J, Beverley PCL, et al. Differential diagnosis of malignant lymphoma and non-lymphoid tumours using monoclonal anti-leukocyte antibody. Cancer 1980;46:2640-7.

14 Warnke RA, Gatter KC, Falini B, et al. The diagnosis of human lymphoma using monoclonal anti-leukocyte antibodies. $N$ Engl $J$ Med 1984;309:1275-81.

15 Nadler LM, Ritz J, Hardy R, Pesands JM, Schlossman SF, Stashenko $P$. A unique cell surface antigen identifying lymphoid malignancies of B cell origin. J Clin Invest 1981;67:134-40.

16 Zola H, McNamara PJ; Moore HA, et al. Maturation of human B lymphocytes-studies with a panel of monoclonal antibodies against human membrane antigens. Clin Exp Immunol 1983;52:655-64.

17 Beverley PCL, Callard RE. Distinctive functional characteristics of human $\mathrm{T}$ lymphocytes difined by $\mathrm{E}$ rosetting or a monoclonal anti-T cell antibody. Eur $J$ Immunol 1981;11:329-34.

18 Evans RL, Wall DW, Platsouscas CD, et al. Thymus dependent membrane antigens in man: inhibition of cell mediated lymphosis by monoclonal antibodies to the $\mathrm{TH}_{2}$ antigen. Proc Natl Acad Sci USA 1981;78:544-8.

19 Abo T, Batch CM. A differentiation antigen of human NK and $\mathrm{K}$ cells indentified by a monoclonal antibody (HNK-1). $J$ Immunol 1981;127:1024-9.

20 Allan PM, Garson JA, Harper EI, Coakham HB, Brownell DB, Kemshead JT. Biological characterization and clinical applications of a monoclonal antibody recognising an antigen restricted to neuroectodermal tissues. Int J Cancer 1983;31:591-8.

21 Korsmeyer SJ, Hieter PA, Ravetch JV, Poplack DG, Waldmann TA, Leder P. Developmental hierarchy of immunoglobulin gene rearrangements in human pre-leukemic pre-B-cells. Proc Natl Acad Sci USA 1981;78:7096-100.

22 Cleary ML, Chao J, Warnke R, Sklar J. Immunoglobulin gene rearrangement as a diagnostic criterion of B cell lymphoma. Proc Natl Acad Sci USA 1984;81:593-7.

23 Arnold A, Cossman J, Bakhshi A, Jaffe ES, Waldmann TA Korsmeyer SJ. Immunoglobulin gene rearrangements as unique clonal markers in human lymphoid neoplasms. $N$ Engl $J$ Med 1983;309:1593-9.

24 Cleary ML, Trela M, Weiss LM, Warnke R, Sklar J. Most null large cell lymphomas are B cell lineage neoplasms. Lab Invest 1985;53:521-5.

25 Knowles DM, Dodson L, Burke JS, et al. SIg-E- ("Null Cell") Non-Hodgkin's lymphomas: multiparametric determination of their B or T cell lineage. Am J Pathol 1985;120:356-70.

Requests for reprints to: Dr W J Smith, Department of Histopathology, School of Medicine, University College London, University Street, London WC1E 6JJ, England 